\author{
Людмила Колсснік \\ Інститут української мови НАН України \\ Київ \\ ORCID: 0000-0003-3321-2942; e-mail: Nezabydka.86@gmail.com
}

\title{
Характерологічні назви в говірках українського Карпатського регіону
}

\begin{abstract}
Реферат: У статті представлено спостереження автора щодо функціонування оцінних слів у говірках українського Карпатського регіону, а саме в гуцульських, закарпатських, бойківських, лемківських говірках та суміжних говірках Буковини й Покуття. Проаналізовано стандартні моделі творення нових віддієслівних та відіменникових похідних. Значну увагу присвячено виокремленню мотиваційних моделей постання метафоричних характерологічних назв. Описано форми міжмовної взаємодії в межах цієї лексичної групи, акцентовано на тісному зв'язку діалектів аналізованого ареалу, що проявляється в спільних тенденціях оцінної номінації.
\end{abstract}

Ключові слова: характерологічна назва, Карпатський регіон, запозичення, мотивація.

Abstract: Valuable words in the dialect of the Ukrainian Carpathian region. The article deals with the functioning of the evaluable words in the dialects of the Ukrainian Carpathians, in particular the Hutsul, Transcarpathian, Boyko, Lemko, Bukovyna and Pokuttya dialects. In these dialects, the lexical system of characterological names is formed according to the same general principles. In the studied dialects, the main universal tendencies inherent in this vocabulary are manifested. On the other hand, original nominations have been observed, resulting from non-linguistic factors

An analysis has been carried out of creating standard models of new words via dialectal nouns and verbs. Much attention has been given to the identification of motivational models behind the emergence of metaphorical characterological names. Unlike standard names, characterological vocabulary is not entered to the passive vocabulary of dialect speakers simultaneously with the disappearance of the actual thing. Secondary names or set similes last longer when they are connected with the material signs of a local culture. The forms of the interlingual interaction in this lexical group have been described. Attention has been drawn to the connections between the dialects spoken in the analysed area, which is reflected in the general trends of the evaluation nomination.

Keywords: evaluable words, the Carpathian region, linguistic borrowings, motivation.

Характерологічна лексика ${ }^{1}$ - широке поняття, що об'єднує різноманітні характеристики: осіб, їхніх дій та станів. За частиномовною належністю це насамперед

${ }^{1}$ Сукупність усіх лексичних одиниць, які не лише називають, а й оцінюють і характеризують, а отже, виконують і називну, і експресивну функції. Їх позначають також термінами: «зображально-виражальні лексичні засоби», «емоційно-експресивні лексичні засоби», «лексичні одиниці емотивного змісту», «образна лексика», «емоційна лексика», «емоційно забарвлена лексика», «характеризуюча лексика», «емоційно-експресивно забарвлена лексика», «експресивний шар (фонд) лексики», 
прикметники, похідні іменники на позначення осіб, експресивні дієслова, прислівники. На відміну від предметної лексики, такі назви виконують не лише денотативну функцію, а й відбивають оцінку мовця відповідних явищ.

В українському мовознавстві такі назви були предметом грунтовних досліджень В.В. Лєснової (2004), В.О. Дворянкіна (2006), Л.Я. Колєснік (2016). Експресивну лексику української літературної мови досліджує Н.I. Бойко (2005).

Характерологічна лексика становить значну частину як словника літературної мови, так і говіркового лексикону, що засвідчують лексикографічні джерела. Наприклад, описуючи емоційно-оцінні слова, зафіксовані в Словнику буковинських говірок, Н.В. Гуйванюк зазначала, що «це надзвичайно поширене явище. У картотеці Словника буковинських говірок нараховуємо 671 лексему, серед яких іменників - 50\%, дієслів - 40\%, прикметників - 9\%, прислівників - 0,9\% й експресивних вигуків - 0,1\%» »(Гуйванюк 2013, 170).

Значна кількість лексикографічних праць, присвячених говіркам українського Карпатського регіону, дозволяє досліджувати характерологічні (експресивно-оцінні) номінації в цьому ареалі.

Територія дослідження охоплює українські терени Карпат від передгір'я до Закарпаття: гуцульські (частина Чернівецької, Івано-Франківської, Закарпатської обл.), бойківські, середньозакарпатські та лемківські говірки.

Джерельною базою дослідження слугували власні записи автора 3 говірок т. зв. Буковинської Гуцульщини (Путильський р-н Чернівецької обл., а також передгірної території Сторожинецького та Вижницького р-нів Чернівецької обл.), діалектні словники різного типу (короткі, словники однієї чи кількох говірок, спеціальні словники, матеріали до словників, словники-додатки до монографій, опубліковані в різний час), а також картотека матеріалів до словника українських говірок Закарпатської області М.А. Грицака, яка зберігається в Інституті української мови НАН України.

Така неоднорідність матеріалів не дозволяє робити кількісні узагальнення, однак дає уявлення про тенденції функціонування оцінної лексики в цьому діалектному просторі. Перевагою деяких словників $\epsilon$ вказівка на конкретну локалізацію та подані ілюстрації, що вияскравлює семантику, мотивацію, стилістичний аспект функціонування слова в говірці. Важливо, що оцінні назви осіб зібрано в спеціальному Словнику оцінних номенів людини в украӥнських діалектах $(\mathrm{COH})$.

Дослідники оцінної лексики суголосні в деяких висновках стосовно досліджуваного об'єкта: щодо переважання номенів із негативною оцінкою над позитивною, кореляції форм чоловічого й жіночого родів, тенденціях у номінації чоловіків і жінок, функціонуванні номенів спільного роду.

Закономірно, що в спостережуваних говірках спрацьовують усі універсальні моделі творення характерологічної лексики. Умовно ії можна поділити на відіменні похідні, віддієслівні утворення та номени, що стали наслідком метафоризації. Хоча, як засвідчує матеріал, вплив метафоричного перенесення помітно відчутний у кожній із цих груп.

«емоційно-оцінна лексика», «стилістично забарвлена лексика», «експресивно-стилістична лексика», «експресивна лексика» (Бойко 2005, 14). 
Серед відіменникових похідних значну частку становлять прикметники, утворені як від питомих, так і від запозичених коренів. Іноді творення відбувається за однаковою моделлю: напр. літ. щзасливий $\leftarrow щ а с т я$, що пох. від псл. sъčęstbje, де $s b$ - 'добрий', решта слова - пох. від с̌ęstb, укр. части́на; отже, первинне значення цього слова 'добра частина' (ЕСУМ, VI, 501). Пор. діал. закарп. партливий (партли́вый) 'щасливий': партли́вый ма́йе парт' на вс'о, веде́ му с'а (KM) Ł парть (nарт) - 1. 'щастя': ти на грибь́ ма́йеш парт', бо усе по́вен ко́шик назбира́йеш (КМ), 2. 'частина, спадок': йак уме́рла старшина́ ко́жджый дуста́в свойу парт' (КМ), 3. 'дружба': оту́ пар'm' нико́ ни роิзоิбйе (КМ); гуц. парть 'щастя, фортуна, доля, талан' (КПР, 133); бойк. парть - 1. 'вміння, хист', 2. 'дар' : він не чаруйе л'удий, а майе таку парт' від Бога, шчо через н'ого мрут', 3. 'щастя' (Онишкевич 1984, II, 42) < від рум. párte 'частина, частка, пай, доля’ (ЕСУМ, IV, 300).

Передбачувано, що на цій прикордонній території побутує чимало запозичень, зокрема зі сх. ром. мов., пор. прикметники та пох. іменники від рум. mut, що має кілька значень-характеристик: 1. 'німий', 2. 'мовчазний', 3. 'негарний', 4. 'дурний’ (РРС, 869); закарп. му́тый 'недорозвинутий чоловік’: йой, якась му́та, нич ти не мо́ж дотолкова́ти (КМ), мутуло́ватый - 1. 'заклопотаний’ (КМ), може бути пов'язане з рум. mutá 'пересуватися' (РРС, 869), 2. 'розумово відсталий' (КМ); му́тул - 1. 'дурень' (КМ): му́туле, пой буде́м іти дому́, та загу́биш (КМ), 2. 'бідолаха' (КМ), 3. 'пес', пох. здріб³. назва мутулик, у якій негативна оцінка пом'якшена. У гуц. гов. натрапляємо на номен му́ma образл. 'неохайна, недбала господиня' (Негрич 2008, 117). Не виявлено лексичних паралелей у словниках бойк. та лемк. говірок, однак у бук. гов., що теж є зоною сх. ром. впливу, зафіксована лексема 'мутол 'мовчазний чоловік' (Колєснік 2016).

У лексемах, утворених уже на українському грунті, часто збережено мотиваційний зв'язок, втілений у запозиченій лексемі, напр., у назвах, що походять від сх. ром. мург 'темно-гнідий': лексема мурта 'плямиста вівця чи корова' (КМ), муртани́стый 'смугастий' (сема 'масть'): бьíла в н'а мургани́ста ко̂ро̂́ва, та н’iвpốку дава́ла дубрі молока́; Такі́ с 'a фа́йн'i йагн'атка муртани́ст 'i накоти́ли (КМ).

Однак більшість похідних зазнає семантичної модифікації на основі нових асоціативних зв'язків:

а) темний $\rightarrow$ брудний: закарп. му́ртавыци 'брудний' (КМ): иди с'а помый, бо дуюже с' му́ртавый (КМ); іменники муртавецฺь (му́ртавиць) 'замазура' (КМ): му́ргави'i ни л'у́бл'ат' мьітис'а (КМ), му́ртавка 'замазура (про жінку)' (КМ): йа з тако̂́y му́ртаўкоิy̆, ги ты, нитде́ ни йду (КМ), му́ргавчя 'тс.' (КМ), бойк. мурга (мурга) 'замазура' (Онишкевич 1984, I, 457), а також експресивні дієслова гуц. му́ртати 'мурзати’ (Сабадош 2008, 177), ми́ргатися ‘мурзатися’ (Сабадош 2008, 177) та віддієслівні іменники, напр., ми́ртанє 'мурзання’ (Сабадош 2008, 177);

б) брудний $\rightarrow$ поганий, недостойний: гуц. му́рга лайл. 'грубіян; забіяка' (ГГ, 127), ‘grubian’ (Janów 2001, 132), лайл. ‘погань, вайло’ (Лесюк 2008, 109), лайл. 'забіяка', 'зла, непривітна людина' (Негрич 2008, 117). Бойк. мурга (мурга) 'мерзотник’ (Онишкевич 1984, I, 457), лемк. мурга лайл. ‘простак, грубіян’ (Турчин

\footnotetext{
2 Ілюстративний матеріал подано відповідно до того, як він представлений у джерелі.

3 У статті збережено стилістичні ремарки до лексем, подані в джерелах.
} 
2011, 182; Пиртей 2004, 179) мають лише похідні значення, і немає жодної фіксації з семантикою кольору, масті.

Деякі характерологічні назви є наслідком прямих запозичень, напр., закарп. дерба́к зневажл. 'нікудишня людина': дербак - неваловшний чулувік (Сабадош 2008, 62). I.В. Сабадош визначає джерелом пол. діал. darebak 'негідник, шалапут', хоча дербак < словац. мови dareba'k 'негідник, шалапут, ледар', пов'яз. 3 darebny' (daremny) 'даремний', утвореним від укр. дар. На українському грунті слово деетимологізувалося (ЕСУМ, II, 35), тобто йдеться про повторне запозичення. У закарп. говірках також $є$ пох. характерологічний прикметник дербакова́тый 'нікудишній (про людину)': тот чулу'вік дербакофватый, у 'н'ого н'іч не иlüе $m^{\prime} p^{\prime}$ ібного (Сабадош 2008, 62).

Одним із видів відіменникових номенів є відсоматизми - лексеми, похідні від назв частин тіла. За усталеною моделлю утворено назви на позначення повного чоловіка від лексеми 'живіт', ‘шлунок' (переважно йдеться про шлунок або нутрощі тварини, що надає новій характерологічній назві відтінку зневажливості): гуц. калю́х (кілюх, колюх) - 1. 'шлунок тварини', 2. зневажл. 'живіт, пузо' (ГГ, 89; Janów 2001, 90), келю́х 'т.с.' (КПР, 77), бойк. ки́люх 'т.с.' (Матіїв 2013, 210); ке́люх -'живіт глечика', 'тельбухи, нутрощі' (Онишкевич 1984, I, 346), закарп. килю́х 'т.с.' (Сабадош 2008, 141); ке̂л’ýx (килю́x) - 1. 'шлунок тварини' (КМ): maкbíu y не̂́ŭi ке̂л’ýx, йак три л’ýдс'кі (КМ), 2. 'випукла частина якогось предмета' (КМ): учини́лас' йі вели́кый кил'ýx, мо́же (копи́u’a) зат 'іка́ти (КМ), 3. згруб. ‘живіт, пузо' (КМ): y на́шого па́на такв́й кил'yx, йак о́зеро (КМ); такь́́й ис' кил'ýx наів, ги буббен (КМ), 4. перен. 'пузатий низький чоловік': ни йди мижи́ ке́л'ухи, бо ты мутузз'аник (КМ). У говірках окресленого ареалу зафіксовано словотвірні гнізда 3 такою твірною основою, зокрема й пох. зменшено-пестл. та згруб. назви: закарп. килюшо́к (КМ), килюши́ще (КМ), пох. дієслово кел уха́ті$m u \rightarrow$ гуц. калюха́тий (колюха́тий) 'товстий, череватий' (ГГ, 89), гуц. келюши́стий (КМ): ідут вівці в полонину самі вакішисті, а за ними вівчарики самі келютисті (KM), kaluchatyj 'brzuchaty', ‘o brzemiennej kobiecie’ (Janów 2001, 90), бойк. килюха́тий зневажл. 'який має великий живіт' (Матіїв 2013, 211), келюха́тий 'череватий’ (Онишкевич 1984, I, 346), закарп. килюха́тый (ки[i]л’уххатый) зневажл. 'череватий' (Сабадош 2008, 141), закарп. ке̂л'уха́тый (кил'у'хатый) - 1. 'т.с.' (КМ): сис' кил 'уха́тый видаў m'ашко ни ро́бит' (КМ), 2. 'великий баран' (КМ). Похідні іменники: гуц. kaluch 'acz' 'człowiek z wielkim brzuchem, brzuchacz, bogacz' (Janów $2001,90)^{4}$, гуц. кєлюха́ч 'пузань; чоловік із великим животом' (КПР, 77); бойк. келюха́ч зневажл. 'черевата дитина' (Онишкевич 1984, I, 346), закарп. килюха́ч вульг. 'т.с.' (Сабадош 2008, 141), келюха́ч (ке̂л'уха́ч, кил'уха́ч) (КМ): із кил'ухача́ шчи чоловік мо́же быти, а горба́того хыба гробова́ до́шка справи́m (КМ) та відповідники жін. роду: kaluchata (żinka) ‘tiażka’ (Janów 2001, 90), килюха́чка вульг. 'товста жінка' (КПР, 141), бойк. килюха́ня зневажл. 'жінка 3 великим животом' (Матіїв 2013, 210), килюха́чка зневажл. 'т.с.' (Матіїв 2013, 211); закарп. килюха́та 'вагітна жінка' (Сабадош 2008, 141), закарп. келюханя 1. 'вівця 3 великим

\footnotetext{
4 У цьому словнику збережено рідкісне на сьогодні переносне значення лексеми kaluch'acz' ‘bogacz' (Janów 2001, 90).
} 
животом': стара́ кел'уха́н'а не̂ л’у́бит йа́zн'a (КМ), 2. 'вагітна жінка'. У таких назвах відчутний метафоричний компонент - порівняння рис зовнішності людини й тварини.

Похідні спільнокореневі номени набувають нових переносних значень, у яких реалізована модель «статура людини чи іiі яскрава особливість - властивість предмета чи дії», напр., пор. похідні дієслова від іменника келю́х: закарп. вь́кел'ушити (ві́кел'ушити, ву́кел'ушити, у́кел'ушити) 'висунути, випнути': йей дуюже вікел'ушив йес копи́щ'y (КМ), вьікел'ушитис'а (віккел'ушитис'а, ву́кел'ушитис'а, у́кел'ушитис'а) 'висунутися, випнутися': мін 'í с'а ви́дит, шо ві́кел'ушилас'а скіна́ повід Грици́шиного (КМ), выкел'ушувати (выкел'ушовати, вікел'у́шувати, укел'у́шувати, укил'у́шувати) 'висувати, випинати': він пу́сто вікел'ýшуйе сі́н з о́борога (КМ), выкел'ушуватис'а (выкел 'ушоватис'а, вікел 'у́шуватис'а, вукел'у́шуватис'а, вукел'ушоватис'а, укел'у́шуватис'а, укел'у́шоватис'а, укил'у́шуватис'а) 'висуватися, випинатися': йа́кос' ми с'а за́паска ду́же вікел'у́шуйе (КМ), дієприкм. вьікел'ушений (вьікел'ушеньй, вікел'ушений, ву́кел'ушений, ву́кел'ушеный, у́кел'ушений, у́кел'ушеный) 'випнутий’: з нияжного бо́ку о́боріг йа́кос' ду́же ві́кел'ушений. (КМ). Однак, ці похідні не мають у своїй семантиці оцінного компонента.

У матеріалах картотеки закарп. говірок збережено цікавий сюжет, пов'язаний iз переносним вживанням соматизма ту́луб $\sigma^{5}$, що також ілюструє згадану мотиваційну модель: у закарп. гов. лексема ту́луб (ту́луn) має значення 'випукла частина посуду’ (КМ): ту́луп корча́zы гото́вый, а корча́zа шче ніт (КМ); пор. похідні тулубля́к 'великий горщик': пӥў ми́йтра дроิy̆ тре́ба спали́ти, до́кё закыпи́т' сисі тулубл'ак (КМ), зменш. тулубля́чок, згруб. тулублячи́ще. Як соматизм ця назва поширена в таких значеннях: 1. 'шлунок людини, тварини': сіло пот'а на ворот'а тай у лапкы дуйе, чорт у н’ому кылкьл пӥрве, а тулуп надуйе (КМ); коли́ ота́к жона́ удурійе та ка́жут: ту́луб пс'а́чий, а ро́зум кот 'а́чий, 2. зневажл. 'живіт': такый у н'ого ту́луn, што ни го́ден с'а зоргну́ти (КМ). Похідні прикметники мають виразне негативно-оцінне значення: тулуба́тый (тулуба́тий) - 1. 'з грубими рисами обличчя': таки́й тулуба́тий - тото́ бу́тріш (КМ), 2. 'череватий’: ой у Хусті дівкы пусті, а в Изі недужі, в Кошелеві тулубаті, а в Липши йак ружі (КМ), як і низка похідних характерологічних іменників: то́́луб 'череватий чоловік': тат' тот то́луб, кіт' да́mо запопа́dе пуд рука́ми, та так тулу́бит', йак бы у оги́н' мета́ ý (КМ), тулуба́нча 'повна дитина': тако́є тулуба́нча, ги у́ттинок із бу́чка (КМ), тулуба́ня (толоба́н'а) зневажл. 'товста жінка, дівчина' (КМ): чом бь така тулуба́н'а не бвіла, кіт' пойіс' за чоловіка (КМ), тулубне́ша вульг. 'незграбна дебела жінка': та'кый 'файный чулу'вік, а жо'на в 'н’ого тулубынеша (Сабадош 2008, 355). Серед похідних зафіксовано експресивне дієслово тулу́біти зневажл. 'багато, з апетитом їсти': хомm'бы йакý му недо́бру стра́ву даў, а йак голо́ден, та буде тулуббіти (КМ).

3-поміж характерологічних віддієслівних лексем частотними є ті, які представляють семи 'не працювати', 'робити щось повільно, напр., ходити і т.д.',

\footnotetext{
${ }^{5}$ В інших говірках (бойк., лем, пок.-бук.) або не зафіксовано лексем із основою тулуб- $з$ оцінною семантикою, або вони функціонують лише в прямому значенні 'тулуб людини': tul'ub (Janów 2001, 242).
} 
оскільки повільність у мовомисленні діалектоносіїв асоціюється насамперед не 3 ретельністю чи охайністю, а з ледарством. Наприклад, дієслово ди́лати 'крокувати, шкутильгати', яке етимологи кваліфікують як твірне від диль 'дошка, брусок, колода', перен. ды́ли 'ноги, ходулі' (ЕСУМ, II, 70), що через посередництво пол. мови запоз. $з$ нім. 'дошка, пілога' (ЕСУМ, II, 70). В описуваних говірках $\epsilon$ твірні слова $з$ такими ж значеннями: пор. гуц. дилина 'груба дошка, брус' (ГГ, 59), бойк. диль, дили́на 'розрізана впродовж колода для настилу у хліві' (Матіїв 2013, 124), лемк. делинь 'підлога, дощане покриття' (Турчин 2011, 80), дblли́на 'брусок, груба дошка для підлоги' (Пиртей 2004, 76) та дієслова без експресивного компонента дылюва́ти 'настеляти підлогу’ (Пиртей 2004, 76).

У матеріалах картотеки закарп. говірок зафіксовано дієслово ды́лати 'повільно йти (про лінивого, хворого)': ни ды́ллай так, бо ми доммӥ тоिвдь́́ и до ве́чера ни дййдеме (КМ); шо так ды́лам, дї́кко, тат' пой ско́рше! (КМ) та похідні - характеристики осіб: ды́лавый 'повільний, лінивий (про людину, що повільно ходить)': йой, што ис'а́ дївка дьілава (КМ); но тот Симко́ дьілавый, хо́дит' ги бы му но́гы по̂путав (КМ); таки́й дв́лавый, шчо ни вылїзе на дерево (КМ); ий Йа́нку, йаки́й ис' ды́лавый, тит' пой ско́рше (КМ) $\rightarrow$ дьілавеu’' (ди́лавищ’) ‘чоловік, який повільно ходить': и́ди тыл, ди́лави'y, най m'а ни ви́жу соิбі́ сперед очи́ (КМ), ды́лавка 'жінка, яка повільно ходить': йа c'a ган'бл'у йти з тако́в ды́ллавко̂в (КМ).

У низці говірок (зокрема в $\mathrm{COH}$, указано поліські, закарп., бук., сх. слоб.) поширена лексема дилда, що є похідним із суф. -д(a) від диль 'дошка, брусок, колода’ (ЕСУМ, II, 69). Зрештою, вона зафіксована й у СУМі з ремаркою «фамільярне»: ди́лда 'здоровило' (СУМ 1971, II, 276).

Дієслово диндати, яке етимологи кваліфікують як звуконаслідувальне, найімовірніше пов'язане з відтворенням звуку, що видає било в дзвоні, напр. пол. dendac' ‘дзвонити, висіти, хитатися’ (ЕСУМ, II, 73), зафіксоване в джерелах у різних фонетичних варіантах, пор.: гуц. ди́ндати 'йдучи, хитатися' (КПР, 48), спільнокореневе лемк. диндилинда́ти (ся) 'теліпатися' (Панцьо 2009, 31; імовірно, наслідок контамінації дієслів диндати й линдати), у закарп. говірках має низку інших значень: ды́ıдати (ды́́ндрати) - 1. 'іти дуже повільно’: так ды́́ндаш, шо не мож позе́рати (КМ); шо так пома́лї дь́́ндраш? (КМ), 2. 'ідучи, стукати ногами об землю’: та вун і до ви́чора не доды́дат' (КМ), 3. 'говорити тихо собі під ніс': тот стариу́н ды́ндат', йак жебра́к (КМ). Ці лексеми стають твірними для інших характерологічних назв: похідного відпроцесуального іменника дыслан'а (ды́ндран'a) 'повільний (лінивий) хід’: ни л'у́бл'y с'а позе́рати на тако́йе ды́́лан'a (KM); ни мо̂́жу с'а ни́кати на тако́й ды́ндран'a (KM) $\rightarrow$ пох. характеристика особи: ды́ндавыцй 'дуже повільний, лінивий’: ды́ндавыцй, шо ле́двы лїзе (КМ), дында́к 'неповороткий чоловік': о́ле йакь́ій дында́к $i$ не ду́мат ' до да́чого с'а вз 'ати́ (КМ); чом, дында́ку, не ро́биш то, шо тй ка́жут'? (КМ); дында́н'а 'лінива жінка': така́ дында́н'a, шо страх (КМ), дь́інда (до́нда) 'лінива людина': ды́нда - таки́й ды́́ндавый (КМ); mbl, ды́ндо, йедна́ (КМ), згруб. ды́ндіско 'недорозвинута людина': то не дївка, а йака́с' непотрі́мна ды́́ндіско (KM).

Як засвідчують матеріали СОН, у пок.-бук., наддніпр., сх. слоб. говірках відомий номен валю́zа зневажл. 'ледар, ледарка' (COH, 36) та похідні, напр. 
валови́тий 'повільний у роботі, вайлуватий' (СБГ 2005, 46). Пор., гуц. валю́га (валю́та) 'т.с.' (ГГ, 33), waluha 'len', wałkon' (Janów 2001, 251), гуц. валюга 'нероба, ледар, волоцюга’ (СГРЯ, 127; СГГЗ 2001, 27; КМ), 'неохайна людина' (СГГЗ, 28), спільнокореневі валю́х 'лінивий, безвідповідальний чоловік' (Голянич 2018, 118), відповідник жін. роду валю́ха 'лінива, безвідповідальна жінка' (Голянич 2018, $118)^{6}$, завальо́н 'неповороткий чоловік, хлопець; лінюх' (КПР, 58), бойк. валькува́тий 'повільний, незграбний у рухах; вайлуватий’ (Матіїв 2013, 50). У закарп. гов. для номінації ледаря зафіксовано лексеми валю́х 'ледар': ваІлуx - ко не н’іч роббти (Сабадош 2008, 35), валягу́в 'неповоротка людина, вайло': ты с тым вал'ацговом м'ного с'а не наробиш (Сабадош 2008, 35), валя́гів (вал'агйв, вал'угі́в, вал'угі́) 'волоцюга, ледар': мно́zо йе на сві́mi вал'агоิву, лехкоро́бу, л'ін'yху́ (КМ), згруб. валяджи́ще 'т.с.' (КМ), валю́гало 'т.с.' (КМ), згруб. валюто́вище ‘т.с.' (КМ), валю́шник (вал’ýшнік) 'т.с.’ (КМ)7; для номінації ледачої жінки поширені три номени: валюха́ня (КМ), валюши́на (уз'а́y̆ соббі́ вал'уши́ну та н'ай тіпи́р' на н'y

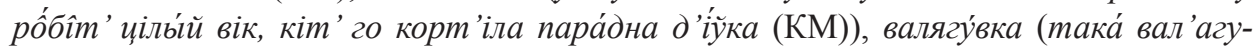
'вка на́ша д'івка, нич не робит', лем с'а всте́рат' у ки́рт 'i (КМ)).

Крім того, у говірках поширені пох. прикметники валюхова́тый 'лінивий': o'ma 'д’вка вал'yхо'вата (Сабадош 2008, 35), завал'ни́стий (завални́стый, завални́стой, завалистий) (КМ) 1. 'лінивий': такой завални́стой, шо лем ним гать затка́ті (КМ), 2. 'повна людина': такий завални́стий Васи́л', што не біру́йе ходи́mu (КМ), пор. також пок.-бук. з'вал'ок 'чоловік-швендя' .

Етимологи пов'язують ці лексеми $з$ дієсловом валити(ся), валятися (ЕСУМ, I, 320), пор. гуц. вальити (ci) одне зі значень 'никати, швендяти туди-сюди' (Лесюк 2008, 92), валєти си 'бити байдики' (СГРЯ, 123), вал'еิтис' $\hat{e}$ ‘байдикувати' (СГГЗ, 27), валєтисе 'забруднюватися' (Голянич 2018, 117), фраз. ити́ / nimú у валю́zи 'податися відпочивати, розважатися, уникаючи роботи' (СГРЯ, 127), лемк. валя́тися 'поневірятися (про людину)' (Пиртей 2004, 37), ‘крутитися’: бі́да не ва́лятся по лісі, лем по л’юдьох (Панцьо 2009, 20).

У говірках Карпатського регіону поширені похідні 3 основою бреск-: гуц. бре́склий 'набряклий, опухлий (про тіло, обличчя)' (Голянич 2018, 96), 'namoknięty, nabrzmiały, spuchnięty' (Janów 2001, 18), збре́склий 'нездоровий; хворий водянкою' (КПР, 66), набре́склий 'нездоровий; хворовитий; промоклий (про дерево)' (КПР, 107), обре́склий 'запухлий, хворий водянкою' (КПР, 122); закарп. набря́злльй (Сабадош 2008, 180) - від псл. *bręk, спорідненого з лит. brinkstu, brinkti ‘набрякати, набухати’ (ЕСУМ, I, 273). У лемк. говірках дієслово бре́скнути (брезкну́ти) 'скисати’ (Панцьо 2009, 19; Пиртей 2004, 33), гуц. брескнути 'т.с.' (СГРЯ, 98-99) та пох. назви 3 перен. значенням щодо людини: збресклий

\footnotetext{
${ }^{6}$ Семантику цього номена вияскравлює контекст: ік йе вин / вал’ýx / то ч’o ни мо́же бу́ти вал'ý. ха? / ка́жут / ad’í вал'ýxа пишла́ (Голянич 2018, 118).

7 У закарп. гов. зафіксовано низку спільнокореневих дієслів із семантикою 'ледарювати': валюта́тися 'вештатися без діла' (КМ), валю́джитися 'т.с.' (КМ), валягува́ти (валагува́ти, валагува́ти, валагова́mi, вал'агова́mи, вал'yхува́ти, вал уххва́mи, вал ’хова́mi) ‘пустувати, байдикувати’ (КМ).

8 Матеріал із бук. говірок уміщено в додатках до нашого дисертаційного дослідження (Колєснік 2016).
} 
(збрескли, збрескви) - 1. 'скисле (про молоко)', 2. 'пригнічений (про людину)' (СПЛ, 69), бойк. збресклий 'прокислий’ (Онишкевич 1984, I, 297), закарп. набре́склий 'намокле дерево’ (СГГЗ, 94), набресклий ‘хвора людина' (СГГЗ, 94). У цьому контексті нез'ясованою є мотивація закарп. прикметника брескливый 'швидкий’: твӥй такый брескливый, што рас-два с'а впа́рит' (КМ).

Особливе місце серед характерологічних назв належить метафоричній лексиці вторинним номенам та лексемам, у яких збережено зв'язок із мотиватором, що $\epsilon$ назвою предмета, явища і под., слова, які вживають у переносному значенні.

Однією з найпродуктивніших у цьому ареалі $є$ так звана «дерев'яна» метафора: творення оцінних номенів на основі метафоричного перенесення назв чи властивостей дерев, деревини або дерев'яних предметів. Частотність ії використання зумовлена позамовними чинниками: природніми умовами, у яких побутують досліджувані говірки, та особливостями господарювання людей на цій території.

Такі номінації можуть бути як позитивними, так і негативними, яких, однак, більше.

Позитивними номінаціями $є$ ті, у яких фізичну силу людини зіставлено з міцністю дерева: напр., гуц. корн'úta 'коренасте дерево; перен. кремезний чоловік' (ГГ, 84; КПР, 84); закарп. дубчи́ско 'великий сильний хлопець’: ге́ле, йакьíŭ дубчи́ско у кумь́ врос (КМ). У бойк. говірках є полярні характеристики: перен. 'нетямуща людина': дуб дубом (Матіїв 2013, 136), дуб'як 'важкодум': тяшко в школі дубяку́ (Матіїв 2013, 136), т. с. у гуц. і суміжних з ними пок.-бук. гов: перен. 'тупа людина'. Хоча трапляються й позитивні порівняння: струнккий йак дуб, 'моцниц йак дуб, 'моиний йак дуб ви'сокиц̆, крепкий йак дуб, втор. номен дуб ' міцний чоловік' (Колєснік 2016).

Дослідники-етнолінгвісти, зокрема О.Л. Березович, зауважують, що

надзвичайна активність «дерев'яної» метафори зумовлена особливими характеристиками дерева, поєднанням у ньому властивостей твердого і м'якого, рослини і матеріалу - до того ж найбільш поширеного... Звідси різноманіття проявів цієї метафори, причому різноманіття не аморфне, а логічно вибудована система взаємодій і переходів, що має яскраво виражену етнокультурну зумовленість (Березович 2007, 145).

В окресленому ареалі поширені такі мотиваційні моделі:

\section{1. Форма, будова дерева - форма ніг, хода людини}

Велике гніздо в закарп. говірках формують похідні назви, утворені шляхом метафоризації від лексеми че́nер 'розросле дерево’: чепе́ра - 1. 'один 3 двох розгалуджених стовбурів', 2. 'людина з кривими ногами’: ой зацвіла чиришин’ка на

9 Пор. бойк. че́nера -1. 'розгалужена смерека або ялина (перев. в ії нижній частині)' (Матіїв 2013, 507), 2. перен., зневажл. ‘особа жіночої статі (переважно молода)’ (Матіїв 2013, 507). 
чотири пера, менні го́ды раховала прокл'ата чепе́ра ${ }^{10}$ (КМ), перен. че́перы зневажл. 'криві й плоскостопі ноги': ба куды́́ вже ть́мми че́nерами Тốніü почепери́тав? (КМ), похідні чепе́равый 'кривоногий’: Васил'о́ва д’іти́на така́ чепе́рова (КМ; пор. лемк. чепера́вий 'кульгавий'), чепера́к зневажл. 'плоскостопий і кривоногий чоловік, хлопець': m'а́шко то̂́му чеперако́ви ме c'a ходи́mu на ста́рости; чепера́ч 'чоловік із кривими ногами': y н'ого чепераўm'i но́zb - чепера́ч; чепери́tош 'т.с.'; чепе́рош 'т.с.' (Сабадош 2008, 414), присл. чепе́раво 'криво' та дієслово чепера́ти (чипир 'ámu, чепе́рати) - 1. 'іти широко розставляючи ноги’ (КМ): чипи́p’ат', йак тота́ ка́чка, 2. зневажл. 'ходити криво': так чепе́рат', ги бы йуй пе́роком но́гы покри́виу (КМ; пор. ще одну фіксацію - зневажл. 'ходити, перевалюючись $з$ однієї ноги на іншу'), чепери́тати 'т.с.' (Сабадош 2008, 414); гуц. чепер 'и́ти 'ходити 3 розчепіреними ногами, незграбно’ (СГГЗ, 160; КПР, 218), бойк. чепера́ти 'повільно йти, маючи криві ноги' (Матіїв 2013, 508), лемк. чепер'яти, чепул'яти 'шкутильгати': чепера́ва На́ста úmb жи́є, за́ўусе люби́ла до нас чепера́ти и да́што повісти (Панцьо 2009, 91).

Це дієслово є твірним для інших похідних: чепера́тый зневажл. 'кривоногий, iз розчепіреними стопами': чепе ратый чулу'вік (Сабадош 2008, 414), чепери́тавый 'т.c.' (Сабадош 2008, 414), пор. гуц. czepiratyj (czipir[n]atyj) 'kosmaty, rozczapierzony, rozczochrany’ - про дерево і про кривоногу людину: czipirata smereka; czipirata diwka (Janów 2001, 31), чепер 'êвий ‘кривоногий чоловік’ (СГГ3, 160), бойк. чепергатий 'гіллястий, розсохуватий’, 'кривоногий’ (Онишкевич 1984, II, 365), лемк. чеператий (чепрати) 1. 'кривоногий, клишоногий (про людину)': чеператий чловек заўсе вигладаў с ”мішним; 2. 'кривий (про дерево)' (СПЛ, 202), 'кривоногий; iз широко поставленими кривими ногами (про людину)’ (Турчин 2011, 338) ${ }^{11}$.

Від цього ж дієслова утворено присл. чеперато 'незграбно (перев. про ходу людини)', пор. бойк. чепергато 'косо, криво', іти чепергато 'косити ногами' (Онишкевич 1984, II, 366); чепера́ня (чипирда́ня, чеи пе ра́ня) 'кривонога жінка, дівчина, яка погано ходить' (КМ): ты шо бре́шеш, чепера́н'o?, зневажл. 'плоскостопа і кривонога жінка, дівчина' (Сабадош 2008, 414) ${ }^{12}$, чепери́тошка 'т.с.', чепе́ро-

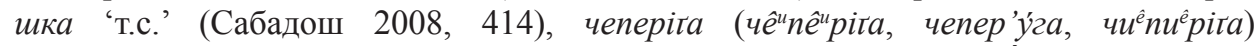

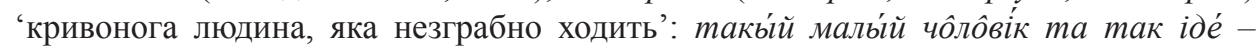
чепер ’’́zа (КМ), пох. жін. роду чеперіта́ня (че̂періта́н'a) (КМ).

\section{2. Дерево або його частина - статура людини}

У низці говірок лексема трам поширена на позначення дерева як матеріалу: напр., бойк. буд. 'підвалина' (Онишкевич 1984, II, 298), закарп. трам 'дерево', 'великий стовбур дерева', ‘кругляк, колода', ‘фундамент дерев’яної хати',

10 Пор. бойк. че́nера -1. 'розгалужена смерека або ялина (перев. в іiі нижній частині)' (Матіїв 2013, 507), 2. перен., зневажл. 'особа жіночої статі (переважно молода)’ (Матіїв 2013, 507).

${ }^{11}$ Пор. також лем. дієслово чеперитися 'широко розставляти ноги (про тварин, людей); широко розпростирати (гілки, коріння)', 2. перен. 'вихвалятися, братися за непосильну справу' (Турчин 2011, 338).

12 Пор. гуц. чепера́н’e (чепера́н’u) ‘людина 3 кривими ногами’ (СГГЗ, 160; КПР, 218). 
спільнокореневі тра́ма 'готове, добре відшліфоване дерево', тра́ми (тра́мы) ‘довге обрубане дерево’ (КМ). Цю лексему засвідчено і в перен. значенні - 'щось надзвичайно велике' - зокрема про статуру людини: така́c’ то́чно йак трам, треба иапіни бы m'a пёднати (КМ), 'дуже товста людина': сис' чоловічи́шче трам (КМ; пор. бук.: Ігодна йак трам 'великоросла жінка' [Колєснік 2016]), а також iii розумові здібності - зневажл. 'дурний’: такый трам, шчо ні в чому с'а не розумійе (КМ).

\section{3. Дерев'яний предмет - статура людини}

Одним із метафоричних перенесень є вживання назв дерев'яних предметів як вторинних номенів з оцінною семантикою. Наприклад, у гуц. гов. Закарпаття вторинний номен пла́ха перен., вульг. 'широкоплеча жінка' (КПР, 142) $\leftarrow$ пла́ха одна половина розколотої колоди’ (КПР, 142). В інших говірках досліджуваного ареалу цю назву зафіксовано 3 такими значеннями: гуц. 'широке бревно' (СГГЗ, 114), 'поміст, на якому у війну страчували людей' (СГГЗ, 114), 'odkłuta (odrąbana) ćwiartka z kloca na 1-2 m’ (Janów 2001, 166), ‘колена дошка' (ГГ, 150); у бойк. гов. вона мала спеціальне призначення: бойк. пла́ха 'широка дошка, на якій розробляють заколоте порося’ (Матіїв 2013, 353).

\section{4. Пошкоджене дерево - лінива або немічна людина}

Пор. гуц. дупла́вий 'дірявий, пошкоджений' (Голянич 2018, 440), ду́давий 'дуплаве дерево' (КПР, 52), дудла́віти 'дуплавіти; перен. підупадати (про людину)' (КПР, 52), 'робитися дуплавим’ (Сабадош 2008, 81); в інших говірках переносних значень не зафіксовано: пор. гуц. 'виникати (про дупло в дереві, дірку в зубі)' (СГРЯ, 480); лемк. дудлистий (дудлисти) 'дуплистий (про дерево)’ (СПЛ, 60).

Ледачу людину порівнюють із непридатним для господаства деревом: гуц. гнилє́к 'гнила колода', перен. 'ледар, здоровило' (ГГ, 46), ‘гнила деревина, фрукт', ‘ледар’ (Голянич 2018, 299), гнили́й ‘зогнилий’, перен. ‘ледачий’ (Голянич 2018, 299; Janów 2001, 70), гнилува́тий 'трохи гнилий', перен. 'лінькуватий’ (Голянич 2018, 299), гуц. гнил'и́к (гнил'е̂к) 'гниле дерево', 'ледачий чоловік, ледар' (КПР, 36; СГГ3, 390), гнилєк (гниіл лек) експрес. - 1. 'щось зогниле', 2. перен. 'лінива людина, ледар' (СГРЯ, 363), гниличчі ‘гнилі або дрібні плоди', згруб. ‘ледащо' (Голянич 2018, 299), пор. також гуц. фраз. гнили́й ік (їк) пень 'дуже лінивий' (Голянич 2018, 299), закарп. погниля́к - 1. 'гниле дерево', 2. перен., зневажл. 'вічно хворий, немічний чоловік' (Сабадош 2008, 238), гниля́к 'т.с.' (Сабадош 2008, 49).

Для характеристики ледачої жінки зафіксовано лексеми гуц. гнили́и’и 'гнила криниця; трясовина', перен. 'ледача жінка' (КПР, 36), закарп. погниля́чка - зневажл. 'хвора, немічна жінка' (Сабадош 2008, 238). У бойк. гов. також є лексеми гнили́й 'гнилий', 'лінивий' (Онишкевич 1984, I, 176), гнили́ия 'лінива жінка', 'нероба' (Онишкевич 1984, I, 176), гнилю́х 'лінива людина, 'нероба' (Онишкевич 1984, I, 176), гни́лус зневажл. 'ледар’: гни́луса - ни руш (Матіїв 2013, 100), гни́люх 
‘т.с.' (Матіїв 2013, 100), гниля́к 1. 'щось зруйноване гниттям', 2. зневажл. 'ледар' (Матіїв 2013, 100), гниль зневажл. 'ледар', фраз. гниль в костьо́х 'відсутність бажання робити що-небудь’ (Матіїв 2013, 100). Об’єктом порівняння, імовірно, могли бути й інші предмети, які зазнали гниття, принаймні, точно не вказано, що це дерево.

Таку ж мотивацію мають назви: гуц. оха́ба 'погань, паскудство' (ГГ, 142), 'parchy, paskuda' (Janów 2001, 146), охабле́ний 'дуже негарний, потворний, страшний' (ГГ, 142), 'brzydki, parszywy' (Janów 2001, 146) Ł оха́ба 'непридатне дерево; гнилизна; негідник' (КПР, 129), закарп. оха́б, оха́ба - 1. 'лісн. дерево, яке залишили на лісосіці не зрубаним для розмноження' (КМ), 2. 'дуже велике старе дерево’: ут'и́в йаку́с оха́бу (КМ). У лемк. гов. поширені пох. дієслова охаби́ти, охабляти 'залишити, покинути' (Панцьо 2009, 59), похаби́тися 'залишити, покинути': похабилися сво́йоi бесіди (Панцьо 2009, 68) та лексему охаб лайл., зневажл. 'незугарна, неохайна, неповажна людина' (Турчин 2011, 224). У бойк. гов. номен оха́ба має лише характерологічне значення: ‘ледар, нероба' (Онишкевич 1984, II, 31), ‘нехлюй’: оха́ба оха́бу на́йде (Матіїв 2013, 327).

\section{5. Процеси, які відбуваються 3 деревом, їхні особливості - вік людини, ії інтелектуальні здібності}

Метафоричне перенесення властивості дерева на позначення риси людини відчутне й у низці інших слів: закарп. трупа́к: 1. 'дерево, яке починає гнити навіть без води': трупак'ú не̂ до́бр'i на будо́ван'а. 2. 'нерозумна людина': ву́звав го учи́тіл' до ма́nbl, жебъ́́ шоิс' указа́в, а вун стойúm', гі трупа́к (КМ). У гуц. говірках номени $з$ таким коренем зафіксовано лише в прямому значенні: гуц. трупи́на 'обвалене дерево' (СГГЗ, 145), трупіна 'стовбур дерева' (СГГ3, 145; ГГ, 189; Janów 2001, 241), тру́nихліти, тру́niшimu 'трухлявіти, гнити' (ГГ, 189), тру́nихлий 'трухлявий’ (ГГ, 189). У бойк. гов. сформована оцінна похідна семантика: бойк. трупехля́к - 1. зневажл. 'гнилувате дерево', 2. 'шматок трухлявого дерева', 3. перен., ірон. 'дуже стара людина': то вже ба́ба таки́й трупехляк, щзо з ниї нич; фраз. стари́ŭ трупехля́к, ірон. 'стара людина': я вже стари́й трупехля́к (Матіїв 2013, 469), трупехля́ча зб. 'дуже стара людина' (Матіїв 2013, 469), пор. закарп. три́хлядь (трухл'u'db, тру́хл’ат', три́хлід’), що є віддієслівним похідним від трухліти (трухніти) 'гнити; трухлявіти': 1. 'трухле, гниле дерево': посто́йало годи́́ де́рево та стру́хло (КМ), 2. 'щось старе, струхнявіле, що розсипається (наприклад, меблі тощо)', 3. перен., зневажл. 'стара, немічна людина' (КПР, 196; Панцьо 2009, 84).

Отже, в характерологічній лексиці говірок Українських Карпат, з одного боку, проявляються основні універсальні тенденції, властиві оцінній номінації, а 3 іншого, - спостережено оригінальні назви, постання яких зумовлене позамовними чинниками. Чимало похідних лексем (зокрема іменників-родових відповідників) утворено за допомогою арсеналу своєрідних словотворчих формантів, які увиразнюють їхнє стилістичне навантаження, є маркерами згрубілості та зневажливості. Аналіз лише словникових матеріалів не дає підстав стверджувати про відсутність 
тієї чи тієї назви в певному локусі, оскільки незафіксовані в словнику номени потенційно можливі в говірках. Тому поповнення емпіричної бази - укладання діалектних словників, записування діалектних текстів - не втрачає своєї актуальності. Характерологічна лексика, на відміну від предметної, не переходить до пасивного словника діалектоносіїв одночасно зі зникненням реалії, у вторинних номенах чи сталих порівняннях довше зберігається зв'язок із матеріальними знаками локальної культури. Утрата такого зв’язку зумовлює перехід назв у розряд лексем із затемненою мотивацію. З'ясування походження оцінних номенів в окресленому ареалі та встановлення затемнених мотиваційних зв'язків $є$ перспективою подальших студій.

\section{Скорочення}

бойк. - бойківський; буд. - будівельне; бук. - буковинський; вульг. - вульгарне; гов. - говірка; гуц. - гуцульський; діал. - діалектне; експрес. - експресивне; жін. - жіночий; закарп. - закарпатський; запоз. - запозичене; зб. - збірне; згруб. - згрубіле; зменш. - зменшене; зневажл. зневажливе; ірон. - іронічне; лайл. - лайливе; лемк. - лемківський; лит. - литовське; лісн. лісниче; літ. - літературне; наддніпр. - наддніпрянський; нім. - німецький; образл. - образливе; перев. - переважно; перен. - переносне; пов'яз. - пов'язане; пок.-бук. - покутсько-буковинський; пол. - польський; пор. - порівняй; пох. - похідне; присл. - прислівник; псл. - праслов'янське; рум. - румунський; словац. - словацький; суф. - суфікс; сх. ром. - східнороманський; сх.слоб. східнослобожанський; т. с. - те саме; укр. - український; фраз. - фразеологізм

\section{Література}

Березович Е.Л. [Berezovich Ye.L.] (2007), Язык и традиционная культура: Этнолингвистические исследования [Yazyik $i$ traditsionnaya kultura: Etnolingvisticheskie issledovaniya], Москва.

Бойко H.I. [Boiko N.I.] (2005), Украӥнська експресивна лексика: семантичний, лексикографічний $i$ функиіональний аспекти [Ukrainska ekspresyvna leksyka: semantychnyi, leksykohrafichnyi i funktsionalnyi aspekty], Ніжин.

ГГ, Гуиульські говірки. Короткий словник [Hutsulski hovirky. Korotkyi slovnyk], Львів, 1997.

Голянич М. [Holianych М.] (2018), Мовний портрет села Tюдів [Movnyi portret sela Tiudiv], Івано-Франківськ.

Гуйванюк Н. [Huivaniuk N.] (2013), Експрасеми розмовного мовлення буковинців як «знаки украӥнської етнокультури» [Eksprasemy rozmovnoho movlennia bukovyntsiv yak "znaky ukrainskoi etnokultury”] [в:] Мова у дзеркалі особистості. Філологічні дослідження, присвячені 80-річчю професора, академіка НАПН Украӥни Кононенка Віталія Івановича [Mova u dzerkali osobystosti. Filolohichni doslidzhennia, prysviacheni 80-richchu profesora, akademika NAPN Ukrainy Kononenka Vitaliia Ivanovycha], Івано-Франківськ.

Дворянкін B.O. [Dvoriankin V.O.] (2006), Номінативні процеси в украӥнських східностепових говірках, дис. ... канд. філол. наук [Nominatyvni protsesy v ukrainskykh skhidnostepovykh hovirkakh, dys. ... kand. filol. nauk], Київ.

ЕСУМ, Етимологічний словник украӥнської мови [Etymolohichnyi slovnyk ukrainskoi movy], т. I-VII, ред. О.С. Мельничук, Київ, 2006. 
КМ, Картотека матеріалів до словника украӥнських говірок Закарпатської обл. М.А. Грицака [Kartoteka materialiv do slovnyka ukrainskykh hovirok Zakarpatskoi obl. M.A. Hrytsaka], (зберігається у відділі діалектології Інституту української мови НАН України).

Колєснік Л.Я. [Koliesnik L.Ya.] (2016), Номінація людини в покутсько-буковинських говірках: генеза та просторове варіювання, дис. ... канд. філол. наук [Nominatsiya liudyny $v$ pokutsko-bukovynskykh hovirkakh: heneza ta prostorove variiuvannia, dys. ... kand. filol. nauk], Київ.

КПР, Піпаш Ю.О., Галас Б.К. [Pipash Yu.O., Halas В.К.] (2005), Матеріали до словника гуиульських говірок (Косівська Поляна і Росішка Рахівського району Закарпатської обл.) [Materialy do slovnyka hutsulskykh hovirok (Kosivska Poliana i Rosishka Rakhivskoho raionu Zakarpatskoi obl.)], Ужгород.

Лесюк М. [Lesiuk M.] (2008), Мовний світ сучасного галицького села (Ковалівка Коломийського району) [Movnyi svit suchasnoho halytskoho sela (Kovalivka Kolomyiskoho raionu)], Івано-Франківськ.

Лєснова В.В. [Liesnova V.V.] (2004), Номіначія рис людини в украӥнських східнослобожанських говірках [Nominatsiia rys liudyny $v$ ukrainskykh skhidnoslobozhanskykh hovirkakh], Луганськ.

Матіїв М. [Matiiv M.] (2013), Словник говірок Центральної Бойківщини [Slovnyk hovirok Tsentralnoi Boikivshchyny], Київ - Сімферополь.

Негрич М. [Negrych M.] (2008), Скарби гуиульського говору: Березови́ [Skarby hutsulskoho hovoru: Berezoví], Львів.

Онишкевич М.Й. [Onyshkevych M.I.] (1984), Словник бойківських говірок, [Slovnyk boikivskykh hovirok], ч. 1-2, Київ.

Панцьо C.Є. [Pantso S.Ye.] (2009), Матеріали до словника лемківських говірок (дієслівна лексика) [Materialy do slovnyka lemkivskykh hovirok (diieslivna leksyka)], Тернопіль.

Пиртей П. [Pyrtei Р.] (2004), Короткий словник лемківських говірок [Korotkyi slovnyk lemkivskykh hovirok], Івано-Франківськ.

PPC, Румынско-русский словарь [Rumynsko-russkiy slovar], Москва - Бухарест, 1980.

Сабадош I.B. [Sabadosh I.V.] (2008), Словник закарпатської говірки села Сокирниия Хустського району [Slovnyk zakarpatskoi hovirky sela Sokyrnytsia Khustskoho raionu], Ужгород.

СГГЗ, Жегуц І., Піпаш Ю. [Zheguts I., Pipash Yu.] (2001), Словник гуиульського говору в Закарпатmi [Slovnyk hutsulskoho hovoru v Zakarpatti], Мюнхен.

СГРЯ, Астаф'єва М.М., Воронич Г.В. [Astafieva M.M., Voronych H.V.] (2014), Словник гуцульських говірок Річки та Яворова: у 4 кн. [Slovnyk hutsulskykh hovirok Richky ta Yavorova: и 4 kn.], кн. 1: $A$-Ж, Івано-Франківськ.

COH, Лєснова В. [Liesnova V.] (2013), Словник оцінних номенів людини в украӥнських діалектаx [Slovnyk otsinnykh nomeniv liudyny v ukrainskykh dialektakh], Луганськ.

СПЛ, Словник прикметникового лексикону лемківських говірок [Slovnyk prykmetnykovoho leksykonu lemkivskykh hovirok], Тернопіль 2015.

СУМ, Словник украӥнської мови: в 11 m. [Slovnyk ukrainskoi movy: v 11 t.], t. 2, Київ 1971.

Турчин С. [Turchyn Ye.] (2011), Словник села Тилич на Лемківщині [Slovnyk sela Tylych na Lemkivshchyni], Львів.

Janów J. (2001), Słownik huculski, Kraków. 